\title{
The New Open Economy Macroeconomics: A Survey
}

\author{
Trinity Economic Paper Series \\ Paper No. 3 \\ JEL Classification: F3, F4
}

Philip R. Lane

plane@tcd.ie

\begin{abstract}
Since the 1995 publication of Obsteld and Rogoff's Redux model, there has been an outpouring of research on open-economy dynamic general equilibrium models that incorporate imperfect competition and nominal rigidities. This paper offers an interim survey of this recent literature.

Keywords: international macroeconomics, nominal rigidities, imperfect competition.
\end{abstract}

\section{Acknowledgements}

Economics Department, Trinity College Dublin, Dublin 2, Ireland. Email: plane@tcd.ie. Homepage: www.economics.tcd.ie/plane. Tel.: 353-1-6082259. Fax: 353-1-6772503. I am grateful to the Social Science Research Council of the Royal Irish Academy and the TCD BESS Benefactions Fund for financial support. I thank Mick Devereux and Harald Hau for helpful suggestions. The views expressed here do not represent the views of the TCD Economics Department. 


\section{Section I: Introduction}

This article surveys some recent efforts by a group of researchers to develop a new workhorse model for open-economy macroeconomic analysis. The unifying feature of this emerging literature is the introduction of nominal rigidities and market imperfections into a dynamic general equilibrium model with well-specified microfoundations.

Imperfect competition - whether in product or factor markets — is a key ingredient in the new models. One reason is that, in contrast to perfect competition (under which agents are price-takers), monopoly power permits the explicit analysis of pricing decisions. Second, equilibrium prices set above marginal cost rationalize demand-determined output in the short-run, since firms are not losing money on the additional production. ${ }^{1}$ Third, monopoly power means that equilibrium production falls below the social optimum, which is a distortion that can potentially be corrected by activist monetary policy intervention.

This approach offers several attractions. The presentation of explicit utility and profit maximization problems provides welcome clarity and analytical rigor. Moreover, it allows the researcher to conduct welfare analysis, thereby laying the groundwork for credible policy evaluation. Allowing for nominal rigidities and market imperfections alters the transmission mechanism for shocks and also provides a more potent role for monetary policy. In this way, by addressing issues of concern to policymakers, one goal of this new strand of research is to provide an an-

\footnotetext{
${ }^{1}$ As is discussed below, this is only true if the shock is not so large as to drive marginal costs above marginal revenues.
} 
alytical framework that is relevant for policy analysis and offer a superior alternative to the Mundell-Fleming model that is still widely employed in policy circles as a theoretical reference point.

In describing the findings of this research program, I focus almost exclusively on the analysis of monetary shocks. This reflects the emphasis in the literature, for the role of nominal rigidities is most starkly illustrated in the case of monetary shocks and it is this kind of disturbance that flexible-price models are least well-equipped to handle.

Obstfeld and Rogoff (1995) is commonly recognized as the contribution that launched this new wave of research and this paper is reviewed in Section 2 below. An important precursor was the paper by Svensson and van Wijnbergen (1989). This paper is a manifesto for sticky-price models that have solid microfoundations and are firmly embedded in an intertemporal setting and the much of the analytic structure of that paper has been adopted in the more recent literature. However, these authors modelled home and foreign outputs as stochastic endowments and the subsequent literature has devoted much more attention to endogenizing the production side of the economy. Krugman (1995) also signalled many of the research issues which have received attention in this new literature.

Finally, it should be noted that the research program described here is very much linked to developments in closed-economy macroeconomics. There is a sense that macroeconomists are converging on a common modelling framework that integrates imperfect competition and nominal rigidities into dynamic general equilibrium models. This recent development has been labelled "neomonetarism" by Kimball (1995) and 
the "new neoclassical synthesis" by Goodfriend and King (1997).

The rest of the paper is organized as follows. The ObstfeldRogoff Redux model is briefly outlined in section 2. Section 3 reviews alternative approaches to modelling nominal rigidity. The impact of market segmentation and pricing to market behavior is discussed in section 4. We turn to the specification of preferences and technology in section 5. Section 6 introduces variation in financial structure. The analysis of international policy interdependence is reviewed in section 7. Section 8 discusses theoretical frameworks that explicitly allow for uncertainty and section 9 alternative approaches to modelling market structure. Small open economy models are the subject of section 10. Section 11 reviews the body of empirical work associated with this new research program. Section 12 concludes.

\section{Section II: Exchange Rate Dynamics Redux}

As was noted in the introduction, Obstfeld and Rogoff (1995) effectively initiated this new research program. ${ }^{2}$ In this section, we brief outline the main features of their Redux model. They set up a two-country model. Each country is populated by a continuum of yeoman-farmers (consumer-producers) that produce differentiated goods $[(0, n)$ live in the home country; $(n, 1)$ in the foreign country]. Preferences for individual $j$

\footnotetext{
${ }^{2}$ The working paper version was released in April 1994 as NBER Working Paper \#4693.
} 
in the home country are given by ${ }^{3}$

$$
U=\sum \beta^{s-t}\left[\frac{\sigma}{\sigma-1} C_{s}^{\frac{\sigma-1}{\sigma}}+\frac{\chi}{1-\varepsilon}\left(\frac{M_{s}}{P_{s}}\right)^{1-\varepsilon}-\frac{\kappa}{\mu} y_{s}(z)^{\mu}\right]
$$

where $\sigma, \varepsilon>0, \mu>1,0<\beta<1$ and $C$ is a CES index aggregating across the differentiated varieties of the consumption good

$$
C=\left[\int_{0}^{1} c(z)^{\frac{\theta-1}{\theta}} d z\right]^{\frac{\theta}{\theta-1}} \quad \theta>1
$$

where $\theta$ is the elasticity of substitution between varieties. Goods $(0, n)$ are produced domestically and $(n, 1)$ overseas: home and foreign goods enter symmetrically into preferences. The corresponding price index is

$$
P=\left[\int_{0}^{1} p(z)^{1-\theta} d z\right]^{\frac{1}{1-\theta}}
$$

$M_{t} / P_{t}$ are the real balances held in period $t$ and the last term in [1] captures the disutility of work effort. There is no capital in the model. It follows from [2] that each consumer-producer faces the constantelasticity demand curve for his output

$$
y(z)=\left[\frac{p(z)}{P}\right]^{-\theta} C^{w}
$$

where $C_{t}^{w}$ is aggregate global consumption. Money is introduced into the economy by the government. Assuming zero government consumption, the revenue earned from money creation is returned in the form of transfers $\left(T_{t}<0\right)$

$$
0=T_{t}+\frac{M_{t}-M_{t-1}}{P_{t}}
$$

\footnotetext{
${ }^{3}$ Analagous equations hold for the representative individual in the foreign country.
} 
Agents have access to an international riskless real bond market at the constant interest rate $r$. The dynamic budget constraint is given by

$$
P_{t} B_{t+1}^{j}+M_{t+1}^{j}=P_{t}(1+r) B_{t}^{j}+M_{t-1}^{j}+p_{t}(z) y_{t}(z)-P_{t} C_{t}^{j}-P_{t} T_{t}
$$

where $B_{t}^{j}$ is agent $j$ 's bond holding in period $t$.

Home and foreign individuals are assumed to have identical preferences and there are no barriers to trade such that the law of one price holds for each good. These assumptions mean that purchasing power parity holds and the consumption-based real exchange rate is constant.

Each agent must decide her optimal choices of consumption, money holding, labor supply and set her optimal output price. Prices are assumed to be set one period in advance, introducing a nominal rigidity into the model. The solution technique is to first solve for a steadystate of the model. To study the dynamic effects of a monetary shock, a log-linear approximation is taken around this steady-state. Since prices are sticky for one period, the solution distinguishes between the impact (first-period) effect of a shock and its long-run steady-state effect. Accordingly, the welfare effect of a shock is calculated as the sum of the short-run change in utility and the discounted present value of the change in steady-state utility.

The authors consider the Dornbusch experiment of a unanticipated permanent increase in the domestic money supply. The impact effect of the monetary shock is an increase in the level of domestic output and consumption. The world real interest rate falls and nominal depreciation translates into a decline in the domestic terms of trade: both factors 
generate an increase in foreign consumption. The impact on foreign output is ambiguous, since the increase in aggregate consumption and the relative price shift work in opposite directions. The domestic current account moves into surplus.

In this case, money is not neutral in the long-run. The short-run domestic current account surplus implies a permanent improvement in domestic net foreign assets. In the steady-state, this implies a permanent domestic trade deficit since a positive net investment income inflow allows consumption to remain permanently above domestic output. The wealth effect of the positive net foreign asset position reduces domestic labor supply (leisure is a normal good) and domestic output, thereby generating a permanent improvement in the home country's terms of trade.

An interesting result is that exchange rate overshooting is not possible in this model. To see this, it is useful to present the equations for PPP and short-run and long-run monetary equilibrium

$$
\begin{aligned}
\tilde{E} & =\tilde{P}-\tilde{P}^{*} ; \bar{E}=\bar{P}-\bar{P}^{*} \\
\tilde{C}-\tilde{C}^{*} & =\bar{C}-\bar{C}^{*} \\
\left(\tilde{M}-\tilde{M}^{*}\right)-\tilde{E} & =\tilde{C}-\tilde{C}^{*} \\
\left(\bar{M}-\bar{M}^{*}\right)-\bar{E} & =\bar{C}-\bar{C}^{*}
\end{aligned}
$$

where “^” denotes short-run values and "-" denote long-run values. ... Since PPP holds, domestic and foreign agents face the same real interest rate and domestic and foreign consumption growth rates are thereby identical. It follows that since the change in the money stock is permanent, the short-run change in relative domestic real balances must equal the 
long-run change and so the permanent increase in the nominal exchange rate just equals its initial jump.

Finally, the monetary shock's impact on home and foreign welfare can be calculated. In evaluating welfare, the disparate effects of the money shock on short-run and long-run values of consumption, real balances and leisure must be aggregated according to the weights implied by the utility function [1]. Remarkably, it turns out that home and foreign welfare are raised by the same amount, despite the asymmetric output effects of the shock. ${ }^{4}$ The intuition for this result is that the first-order effect of the monetary shock is the initial general increase in world demand. Since the imperfect competition distortion means that the initial level of output was too low, a demand-driven increase in world output raises welfare, to the equal benefit of both countries. ${ }^{5}$ The expenditureswitching and terms of trade effects of the shock are only of second-order importance, since optimizing agents would have initially set the marginal utility of extra revenue equal to the marginal disutility of extra work effort. So the fact that home agents produce more does not raise their relative utility level: the extra revenue is exactly cancelled out by the increase in work effort. In similar fashion, current-account imbalances have only second-order effects, since the initial equilibrium leaves unexploited any marginal gains from reallocating consumption and leisure across time periods.

\footnotetext{
${ }^{4}$ This statement ignores a minor extra gain to domestic agents from a permanent increase in real balances.

${ }^{5}$ The mechanism is exactly the aggregate demand externality highlighted by Blanchard and Kiyotaki (1987).
} 
This example vividly demonstrates the benefits of using a microfounded model. In assessing the net impact of a shock that has myriad effects, some metric is required and the representative agent's utility function is the obvious choice in evaluating welfare. The surprising result that both countries gain equally from an unexpected domestic monetary expansion illustrates the utility-based evaluation offers a non-trivial advantage over traditional ad-hoc loss functions.

Many of the assumptions in the Redux model have been modified in subsequent work. In the following sections, we discuss the impact of these revisions to the basic framework. We will show that the international transmission and welfare effects of monetary shocks prove to be quite sensitive to the precise specification of price stickiness, preferences and financial structure, to name just a subset of relevant factors.

\section{Section III: Nominal Rigidities}

The literature typically introduces nominal rigidity as an exogenous feature of the environment. ${ }^{6}$ In the Redux model, firms simultaneously set prices one period in advance. This assumption is arbitrary but convenient, since all adjustment is completed after just one period. Clearly, if price stickiness is motivated by an underlying fixed menu cost, firms will be motivated to immediately adjust prices in the event of a large enough shock. Indeed, as Corsetti and Pesenti (1998) emphasize, a sufficiently large shock would violate firms' participation cost by raising

\footnotetext{
${ }^{6}$ An exception is Beaudry and Devereux (1995) which generates endogenous price stickiness as an equilibrium in a stylized model of increasing returns to scale.
} 
marginal cost above price. As such, the analysis should be interpreted as applying only to the relevant range of shocks. That said, if we think of monetary shocks as emanating from policy decisions, policymakers would take this constraint into account when deciding the size of the stimulus to unleash on the economy. Finally, nominal rigidity is invariably modelled in this literature as of the time-dependent variety, since state-dependent pricing is not easily incorporated into general equilibrium models.

\section{A : Sticky Wages}

The literature has largely emphasized price stickiness as the locus of nominal rigidities, for the reasons discussed by Kimball (1995). ${ }^{7}$ Hau (1998) rather considers a case in which prices are flexible but nominal wages are predetermined. ${ }^{8}$ Both product and labor markets are monopolistic, since each household supplies a differentiated labor input. Facing a constant elasticity of demand, monopolistic firms set prices as a constant markup over the wage. For this reason, since wages are sticky, optimal prices also remain fixed in the short run and the factor market rigidities in effect produce the same international transmission effects as the domestic product price rigidities in the Redux model. ${ }^{9}$

\footnotetext{
${ }^{7}$ However, Bergin (1995) makes arguments in favor of wage stickiness as preferable to price stickiness.

${ }^{8}$ Obstfeld and Rogoff (1996, Section 10.4.2, pp 709-711) provide a textbook treatment of Hau's model.

${ }^{9}$ With identical and constant elasticity of demands across countries, it is hard to reconcile price flexibility with violations of the law of one price (see Section 4 below). However, with internationalized production by which local labor is used to produce for the local market, local wage stickiness can translate into rigid prices in local currency, even when firms are free to costlessly alter prices.
} 
$B$ : Staggering

Simultaneous one-step-ahead pricing has the counterfactual implication that the price level evolves in large, discrete jumps. Staggered price setting is an alternative way to introduce price stickiness that permits smooth price level adjustment. This staggering means that each firm must take into account the previous and future pricing decisions of other firms in optimally setting its price. Many authors follow Calvo (1983). The Calvo pricing assumption is that the opportunity to adjust its price arrives stochastically to each firm. Independence across a large number of firms means that a fixed fraction adjusts its price each period so that the price level is a smooth variable and changes only gradually over time: if the Poisson arrival rate of a price-change opportunity is $\gamma$, a fraction $\gamma$ of firms changes its price each period and $1 / \gamma$ is the average interval between price changes for a given firm.

As previously analyzed by Taylor (1980) and Blanchard (1983), staggering is a potential persistence mechanism since the adjustment to a shock cannot be achieved instantaneously. ${ }^{10}$ Kollmann (1997) calibrates a model in which both prices and wages are sticky. He compares predetermined price and wage setting to Calvo-type adjustment rules in responding to monetary shocks and finds that Calvo-type nominal rigidities perform better in matching the high observed serial correlation of nominal and real exchange rates and the gradual adjustment in the price level but less well in matching the correlations of output with other macroeconomic

\footnotetext{
${ }^{10}$ Taylor considers staggered wage contracts; Blanchard makes the adaptation to analyze staggered pricing.
} 
variables.

In general, the responsiveness of prices and persistence depend on (i) the sensitivity of prices to costs; and (ii) the sensitivity of costs to output. Chari et al (1998a) show that staggering in itself does not generate endogenous persistence if prices are a constant markup over marginal costs and if marginal costs are increasing in the level of output. Under these conditions, a firm will raise its price as soon as it is given the opportunity. However, if firms face convex demand schedules, such that the price elasticity of demand is increasing in the price charged, firms will be slower to raise prices. Moreover, Jeanne (1998) considers a Calvo pricing model in which real wages are rigid, in the sense of being inelastic to shifts in output and employment. He shows that a firm, when it receives the opportunity to alter its price, only makes a small adjustment: if marginal costs are rigid, optimal prices will also be sticky. Real-wage rigidity thereby amplifies the real effects of monetary shocks and increases persistence.

Andersen (1998) makes the point that wage staggering is more likely to generate persistence than price staggering, since wage stickiness implies that labor demand rather than labor supply determines quantities in the labor market. For this reason, the elasticity of labor supply is irrelevant in determining short-run marginal costs. Finally, Bergin and Feenstra (1998a, 1998b), discussed below, show how non-constant elasticity of demand and intermediate inputs can also generate persistence in a staggering framework. 


\section{Section IV: Market Segmentation and Pricing to Market}

By assumption, the law of one price always holds in the Redux model. Engel (1998) and others have documented that international deviations in tradables prices are responsible for a large proportion of real exchange fluctuations. ${ }^{11}$ In line with this empirical evidence, a number of authors have introduced international market segmentation into the baseline model.

Segmentation means that at least some firms have the ability to charge different prices for the same good in home and foreign markets. Second, it is assumed that prices are sticky in each country in terms of the local currency. With identical CES preferences across countries, even these firms will optimally select home and foreign currency prices that are a constant markup over marginal cost and hence the law of one price will be satisfied ex ante. In the event of a shock, however, prices that are sticky in each local currency means that exchange rate movements cause ex-post deviations from the law of one price. Pricing to market (PTM) in combination with local-currency sticky prices, thereby allows the real exchange rate to fluctuate and delinks home and foreign price levels. ${ }^{12}$

\footnotetext{
${ }^{11}$ For surveys, see Rogoff (1996) and Devereux (1997).

${ }^{12}$ Since local-currency sticky prices, or destination market rigidities, are a key ingredient, that argument that PTM is a mislabelling for the reason that PTM strictly refers to the ability of firms to optimally choose different prices for different markets. However, the term is now commonly used in the literature. Goldberg and Knetter (1997) refer to it as "short-term" PTM to distinguish it from the flexible-price case.
} 


\section{A : Pricing To Market}

Betts and Devereux (1998a) modify the Redux model by assuming a fraction $s$ of firms can set different prices in home and foreign markets. ${ }^{13}$ As such, the parameter $s$ indexes the extent of PTM. Since the expenditure-switching effect of exchange rate movements disappears under PTM, changes in the exchange rate have a limited impact on consumption and hence the size of the exchange rate movement required to satisfy the monetary equilibrium condition is enlarged. This raises the possibility of short-run exchange rate overshooting, which is ruled out in the Redux model.

Moreover, since home and foreign price levels are sticky, a movement in the nominal exchange rate shifts the real exchange rate and delinks home and foreign consumption growth. In contrast, the correlation of home and foreign output rises since the domestic demand expansion raises demand for imports at the fixed relative price of imports in terms of domestic currency. In this way, the model generates international consumption and output comovements that are more in line with the evidence on international business cycles. Finally, with full PTM $(s=1)$, the current account remains in balance, contrary to the surplus situation in the Redux model.

A noteworthy result is that an exchange rate depreciation can actually improve a country's terms of trade under PTM. The reason is that export prices are fixed in terms of foreign currency so depreciation raises

\footnotetext{
${ }^{13}$ Betts and Devereux (1996) lay out a static version of their model.
} 
the corresponding domestic-currency "price" of exports without altering domestic-currency import prices. Contrary to the Redux model, a surprise home monetary expansion can thereby have a beggar-thy-neighbor effect by adversely affecting the foreign country's terms of trade.

Betts and Devereux (1997) calibrate a version of their PTM model that allows for staggering and capital accumulation. They show that the PTM model does well in matching the conditional moments in the data and clearly outperforms the PPP-based Redux model which cannot generate real exchange rate movements or high international output correlations relative to consumption correlations.

Chari et al. (1998) similarly calibrate a PTM model but rather attempt to match the unconditional moments in the data. A key result is that, even when firms set prices in staggered fashion, the model is unable to generate a persistent effect on real exchange rates beyond the period of exogenously-imposed nominal stickiness. As was noted earlier, the reason is that a flexible labour market means that marginal costs rise in response to an increase in aggregate output. Since constant-elasticity demand schedules mean that the optimal markup is fixed, an increase in marginal costs induces firms to raise prices proportionally as soon as they have the opportunity to make the adjustment.

\section{B : Translog Preferences}

Bergin and Feenstra (1998a) also study PTM but depart from the monopolistic competition framework in which firms face constantelasticity demand schedules. They consider translog preferences, by which 
the expenditure share for each good $j$ is inversely related to its relative price, which generate variable markups over marginal cost. Following Basu (1995), they also introduce intermediate goods into the production structure, so that marginal costs are heavily influenced by the aggregate price level (good can be demanded either as intermediate inputs or for final consumption). Firms are assumed to set prices in a staggered fashion. In this setup, monetary shocks have persistent effects on real exchange rates, even after all firms have had the opportunity to adjust prices. The intuition is that each firm is reluctant to raise its price when other prices remain fixed both because an increase in relative price reduces its expenditure share and because the fixed prices of other goods means that the cost of intermediates, and hence total marginal cost, does not rise quickly. A variable markup over marginal cost means that deviations from the law of one price also persist. This stands in contrast to the other PTM models that specify a constant elasticity of demand (and thereby a constant markup): in that case, once firms are free to adjust prices, the law of one price will be re-established. As such, PTM does not in itself generate endogenous persistence beyond the length of the exogenous nominal rigidity in the model. ${ }^{14}$ One consequence of the slow adjustment induced by translog preferences is a larger accumulation of net foreign assets and hence there is a bigger long-run impact on the real exchange rate.

An interesting feature of the model is that, if the parameters for the interest and consumption elasticities of money demand are set

\footnotetext{
${ }^{14}$ Indeed, as shown by Friberg (1998), such concavity in the demand function is a necessary condition for risk-averse firms to find it optimal to preset export prices in the foreign currency.
} 
so as to induce exchange overshooting, persistence raises the volatility of exchange rates: since the interest rate differentials persist for several periods, the exchange rate must be expected to depreciate for several periods consecutively and, as such, the initial jump in the exchange rate must be more extreme. That said, a larger exchange rate response alters marginal costs and hence induces faster price adjustment, reducing the persistency of the impact of a monetary shock on real variables such as the level of output.

As shown by Bergin and Feenstra (1998b), both translog preferences and intermediate inputs can independently generate endogenous persistence, with the implication that only one of these features must be present to deliver persistence. However, they also show that there is a positive interaction between the two mechanisms: a greater share for intermediates in the production function generates more persistence under translog preferences relative to the CES case.

\section{Section V: Preferences and Technology}

Specifying household preferences is a key decision in any microfounded model. There is a long list of critical parameters to be selected, including the intertemporal elasticity of substitution, the elasticities of substitution between different varieties of a given class of good; between home and foreign goods; between traded and nontraded goods; between consumption and leisure; between private and government consumption; and, finally, the consumption and interest rate elasticities of money demand. 


\section{A : Consumption Preferences}

The Redux model makes no distinction between home and foreign produced goods in specifying preferences: all varieties enter symmetrically into the aggregate CES index. The earlier work of Svensson and van Wijnbergen (1989) instead assumed that home and foreign goods were substitutable only to a limited degree and asymmetric preferences over home and foreign goods have recently been re-investigated by several authors. Chari, Kehoe and McGrattan (1998a) model the home final good as produced from intermediate goods produced in the home and foreign countries $^{15}$

$$
y=\left[\omega_{1}\left(\int_{0}^{1} y_{H}(i)^{\theta} d i\right)^{\rho / \theta}+\omega_{2}\left(\int_{0}^{1} y_{F}(i)^{\theta} d i\right)^{\rho / \theta}\right]^{\frac{1}{\rho}}
$$

where $1 /(1-\theta)$ is the elasticity of substitution between different varieties of a given category of goods, $1 /(1-\rho)$ is the elasticity of substitution between home and foreign goods and the parameters $\omega_{1}, \omega_{2}$ and $\rho$ determine the ratio of imports to GDP. In their calibration, $\theta$ and $\rho$ are set such that the elasticity of substitution between home and foreign goods is less than the elasticity of substitution between different varieties of the home and foreign goods and $\omega_{1}$ and $\omega_{2}$ such that there is marked home bias in consumption.

The analytics of a limited elasticity of substitution between home and foreign goods are well illustrated by Corsetti and Pesenti (1998). In their model, the law of one price is retained and total consumption is a

\footnotetext{
${ }^{15}$ It is straightforward to transform the model so the home and foreign differentiated goods enter direcltly into consumption.
} 
Cobb-Douglas aggregate over home and foreign goods

$$
C=C_{H}^{\gamma} C_{F}^{1-\gamma}
$$

which implies a unit elasticity of substitution between home and foreign goods. ${ }^{16}$ In turn, this implies constant income shares for home and foreign agents: if domestic output rises relative to foreign output by 10 percent, the relative price of home goods falls by 10 percent. The risk-sharing provided by such offsetting terms of trade movements renders securities markets redundant and the equilibrium current account is always zero in this setup. ${ }^{17}$ A zero current account means that shocks have no long-run effects and this feature allows the authors to write a version of the Redux model that is solvable in closed form, without resorting to linearizations. In addition, the model is tractable without imposing complete symmetry across countries, so that the impact of structural differences across countries (e.g. unequal country sizes or variation in key parameters) can be analyzed. This flexibility makes it possible to derive optimal policies as functions of structural parameters and the policy stance of the rest of the world.

The capability to analyze non-infinitesmal shocks reintroduces the terms of trade as an important channel by which relative output movements affect welfare. Indeed, the authors show that a domestic monetary expansion can be "too large" in the sense that the positive welfare effect of an increase in home output can be more than offset by a decline in its

\footnotetext{
${ }^{16}$ However, this formulation means there is no home bias in consumption: domestic and foreign households choose the same consumption bundle.

${ }^{17}$ See also Cole and Obstfeld (1991).
} 
terms of trade. This implies that the optimal monetary surprise is finite in magnitude, unlike in the Redux model. In related fashion, it is not optimal for an individual country to choose a monetary surprise so large as to raise output to its competitive level, since this would unduly weaken its terms of trade. More generally, unlike in the Redux model, the terms of trade mechanism means that monetary surprises do not have symmetric welfare effects across countries, re-establishing international policy interdependence as a source of potential conflict (see section 7 below).

\section{B : Consumption Elasticity of Money Demand}

The consumption elasticity of money demand does not affect the volatility of the exchange rate in the Redux model. Under PPP, each country faces the same real interest rate and consumption growth rates are identical across countries, with the implication that exchange rate overshooting does not occur in response to shocks: the volatility of the nominal exchange rate is just equal to the volatility of the underlying monetary shocks.

Under PTM, in contrast, home and foreign prices for the same good can diverge and the consumption elasticity of money demand reemerges as a key parameter in determining the nominal exchange rate response to a shock. Betts and Devereux (1998a) show how exchange rate volatility is an inverse function of the consumption elasticity of money demand. The intuition is the same as for the output elasticity of money demand in the original Dornbusch overshooting model: a low consumption elasticity of money demand means that the interest rate must fall to clear the money 
market in the wake of a monetary expansion; in turn, a fall in the interest rate is possible only if the exchange rate is expected to appreciate, generating the overshooting phenomenon. Aside from PTM, an alternative method to allow for real exchange rate fluctuations is to allow for nontraded goods or home bias in consumption, as in the models reviewed below in section 5.5. The consumption elasticity of money demand plays the same role in generating exchange rate volatility in these models as in PTM settings.

\section{C : Consumption-Leisure Nonseparability}

In the Redux model, consumption and leisure enter separably into preferences. A potential criticism of this assumption is that it is incompatible with a balanced growth path if trend technical progress is confined to the market sector: as a country grows richer, labor supply continually declines, converging to a situation in which labor supply is zero. ${ }^{18}$ Chari et al. (1998) alternatively consider benchmark preferences that are standard in the real business cycle literature and are consistent with a balanced growth path

$$
U(C, l, M / P)=\left[\left(a C^{\nu}+(1-a)(M / P)^{\nu}\right)^{\frac{\gamma}{\nu}}(1-l)^{1-\gamma}\right]^{1-\sigma} /(1-\sigma)
$$

which imply a unit elasticity of substitution between consumption and leisure. With these preferences, a monetary shock that increases relative domestic output also leads to raised relative domestic consumption in

\footnotetext{
${ }^{18}$ Balanced growth is still possible in this case if there is a unit intertemporal elasticity of substitution.
} 
order to compensate for the extra work effort. This has the effect of mitigating the impact of monetary shocks on the real exchange rate, reducing the ability of monetary shocks to explain the high observed volatility in real exchange rates. ${ }^{19}$

For this reason, Chari et al. (1998) argue that preferences separable in consumption and leisure are required in order to explain high exchange rate volatility. Accordingly, their preferred preferences are

$$
\begin{aligned}
U(C, l, M / P)= & {\left[\left(a C^{\nu}+(1-a)(M / P)^{\nu}\right)^{\frac{1}{\nu}}\right]^{1-\sigma} /(1-\sigma) } \\
& +\psi(1-l)^{1-\xi} /(1-\xi) \quad \xi>0
\end{aligned}
$$

This specification can be made compatible with balanced growth if we assume that the productivity of non-market activity rises in line with productivity in the market sector: in this case, a fixed amount of time allocated to non-market activity generates a growing amount of leisure services over time. It is worth noting that $\sigma=\xi$ is also required for balanced growth, which connects the labor supply elasticity to the intertemporal elasticity of substitution in consumption. The more elastic is labor supply / the greater the intertemporal elasticity of substitution in consumption, the more volatile are real exchange rates.

\footnotetext{
${ }^{19}$ That said, as is illustrated by Bergin (1998), the enhanced positive comovement between domestic output and domestic consumption helps to explain how demand shocks can be reconciled with small current account imbalances. See also Kimball (1995) on the role of nonseparability between consumption and leisure in business cycle models.
} 


\section{$D:$ Adding Capital}

Labor is the only factor in the Redux model. Since output is demand-determined in the short-run, this parsimonious modelling of the supply-side may be justified by appealing to enhanced tractability. However, Chari et al (1998a) argue that adding capital is important, since monetary shocks can cause investment booms by reducing the short-run interest rate. In turn, this means that a monetary shock may actually generate a current account deficit, in contrast to the Redux prediction of a surplus. It is worth noting that the impact of the investment boom is to raise current relative to future labor supply, such that the persistence of shocks is diminished. Betts and Devereux $(1997,1998 \mathrm{~b})$ also document the role of investment in the propogation of monetary shocks.

\section{E : Nontraded Goods and Home Bias}

Hau (1998) introduces nontraded goods into the analysis. ${ }^{20}$ The preference structure is the same as in the Redux model but it is assumed that a fraction of home and foreign goods are nontradable for technological reasons. ${ }^{21}$ Hau shows that the presence of nontradables increases the size of the initial exchange rate response to a monetary shock: since nontraded prices are tied down by the sticky nominal wage, a larger exchange rate movement is required to accomplish a given change in the aggregate price level. Second, the presence of nontraded goods means

\footnotetext{
${ }^{20}$ Small open economy models with nontraded goods are discussed in section 10 below.

${ }^{21}$ As such, nontradables are introduced in a utility-independent manner. This stands in contrast to the typical procedure of treating traded and nontraded goods as imperfect substitutes in consumption.
} 
that the demand expansion is biased towards home goods, raising domestic relative to foreign consumption. Third, since the real exchange rate is expected to appreciate in the transition to the new steady-state, the consumption-based real interest rate is low at home relative to overseas, again leading to a wider consumption differential. The latter two factors reduce the price level response to a monetary shock and hence partly offset the increase in exchange rate volatility induced by the presence of nontradables. Finally, high exchange rate volatility in Hau's model is coterminous with high volatility of the relative price of imports relative to domestically produced goods, which is not a pattern clearly observed in the data.

Warnock (1998) rather considers home bias in preferences for tradable goods: domestic consumers gain higher utility from consumption of domestic tradables and their foreign counterparts have a corresponding preference for foreign tradables. ${ }^{22}$ This stands in contrast to the Redux assumption of symmetric preferences across goods, regardless of nationality. Under home bias, a domestic monetary expansion improves home welfare by more than foreign welfare, so that the gains are not equally shared, again in contrast in the Redux model. The intuition is simple: relative demands for home and foreign goods now depend not only on relative prices but also on the composition of global spending between domestic and foreign agents. Accumulation of net foreign assets now has wealth effects on relative prices via the composition of demand in addition

\footnotetext{
${ }^{22}$ Chari et al (1998a) allow for home bias in their numerical simulations but do not analyze its impact in any detail.
} 
to the labor supply channel. Since the real exchange rate now depends on the terms of trade, the real exchange is no longer a constant and, relatedly, nominal exchange rate overshooting occurs in response to a monetary shock.

\section{Section VI: Financial Structure}

The Redux model allowed only international trade in a riskless real bond. Obstfeld and Rogoff defend this assumption on the basis that it would be strange to analyze imperfections and rigidities in goods markets but at the same time assume the completeness of international capital markets. Conversely, it is hard to imagine how price or wage rigidities could survive in a world sufficiently sophisticated that complete international risk sharing is accomplished.

\section{A : Financial Market Completeness}

Under complete markets and the law of one price, full risksharing means that there are no shifts in wealth arising from monetary shocks. This rules out the persistence channel embodied in the Redux model by which a shift in relative wealth has a permanent effect on relative labor supplies and hence relative outputs and relative prices. ${ }^{23}$ As such, the complete markets assumption serves to simplify the analysis by eliminating the current account and net foreign assets as a dynamic propogation mechanism.

\footnotetext{
${ }^{23}$ Were there home bias in consumption preferences, a relative wealth shift would also affect the terms of trade and the real exchange rate via a relative demand shift.
} 
In their PTM model, Chari et al. (1998) compare the effects of monetary shocks under complete markets versus when only an uncontingent domestic-currency nominal bond is traded. It turns out that the incompleteness of financial markets makes little difference for the persistence of monetary shocks in this context, since equilibrium current account movements are small. The explanation is that, under PTM, home consumption of both domestic and foreign goods rises but foreign consumption is little changed when a positive domestic monetary shock occurs but the increase in domestic imports is financed by an increase in the domestic currency value of export earnings, since foreign currency prices are fixed and the exchange rate depreciates. Indeed, under log-separable preferences, the current account exactly remains in balance so that there are no persistent effects of the monetary shock.

Betts and Devereux (1998b) find a similar result. Indeed, they show that the international transmission of monetary shocks is not much different between these two asset market structures even when the law of one price holds, since equilibrium current account movements are quantitatively small. ${ }^{24}$ However, Tille (1997) points out that financial structure does in general qualitatively alter the current account response to a monetary shock under PTM. For instance, if only a home-currency nominal bond is traded, anticipated exchange rate movements alter the real interest rate facing foreign households and hence tilt their optimal consumption path.

\footnotetext{
${ }^{24}$ That said, these authors show that the asset market structure is extremely important for the transmission of fiscal shocks. The denomination of sticky prices, in contrast, is relatively unimportant for the fiscal case.
} 
The unit elasticity of substitution between home and foreign goods proposed by Corsetti and Pesenti (1998) and adopted by Obstfeld and Rogoff (1998) sidesteps the issue, since constant income shares for home and foreign agents and as such make securities markets redundant. However this trick does not work under PTM since home and foreign price levels are delinked and exchange rate depreciation is not synonymous with a deterioration in the terms of trade.

\section{$B$ : Trading Frictions}

Trading frictions are introduced by Sutherland (1996) who assumes that only bond trade is possible but the purchase of foreign bonds involves convex adjustments costs. The impact of the trading frictions is to allow the domestic interest rate to deviate from the foreign interest rate. In the event of a domestic monetary shock, the domestic interest rate declines and a negative interest rate differential develops. Associated with a negative interest rate differential is a larger jump in relative domestic consumption and these factors imply a smaller exchange rate depreciation. In turn, this implies domestic output rises by less. Finally, the exchange rate undershoots its long-run level. As such, imperfect financial integration leads to lower volatility in the exchange rate and consumption but larger volatility in output and interest rates. Unsurprisingly, consumption tracks output more closely and accordingly current account imbalances are smaller.

Sutherland specifies Calvo-style nominal rigidity. An interesting result is that barriers to financial integration have a larger impact, the 
greater the degree of price inertia (i.e., the more rarely do firms adjust prices). The intuition is simple: the greater is price inertia, the slower is the adjustment of output to shocks and the more agents want to smooth consumption via international financial markets.

Senay (1998) adapts the Sutherland model to additionally incorporate goods market segmentation and PTM behavior. She considers a variety of monetary, fiscal and productivity disturbances. In most cases, she finds that there is very limited interaction between the extent of financial market integration and goods market integration in determining the macroeconomic effects of shocks. However the role of financial market integration in determining the output response to a monetary shock depends critically on the extent of goods market integration: Senay shows that financial market integration reduces the output response to a monetary shock if goods markets are segmented but actually increases the output response if goods markets are integrated.

\section{$C:$ Money Shocks and Asset Prices}

Finally, Kollmann (1998) points out that dynamic general equilibrium models with nominal rigidities are relevant in explaining the impact of monetary shocks on equity markets, since profit levels (and hence dividends) are affected by monetary shocks in these models. In his model, he allows for international bond trade but equity is only domestically traded. He studies the impact of monetary shocks on equity and bond returns. Monetary shocks generate volatile asset returns but the predicted cross-country correlations of rates of return on bonds and equity are much 
smaller than those observed in the data.

\section{Section VII: International Policy Interdependence}

One of the obvious applications of the new models is to revisit the economics of international monetary policy interdependence. In the language of Cooper and John (1988), the key questions to ask are whether monetary policies have positive spillover effects (i.e. does a foreign monetary expansion raise domestic welfare?) and whether home and foreign monetary policies are strategic complements or substitutes (i.e. does a foreign monetary expansion induce the home central bank to expand, contract or leave unchanged the domestic monetary stance?). In the Re-

dux model, monetary policies have positive spillover effects but home and foreign monetary policies are strategically independent.

In the Corsetti-Pesenti model introduced above, as in the Redux model, a surprise monetary expansion always has a positive spillover effect on the welfare of the other country, via the decline in the world interest rate and the improvement in its terms of trade. However, in this setup, the sign of the policy response function depends on the interplay between the intertemporal elasticity of substitution and the intratemporal elasticity of substitution between home and foreign goods. (The latter is fixed at unity due to the Cobb-Douglas preferences.) If the intertemporal elasticity is larger than the intratemporal elasticity, policies are strategic substitutes: the home central bank responds to a foreign monetary expansion by contracting domestic monetary policy. The reason is that, under this parameter combination, the foreign expansion raises domestic 
output relative to its initial optimized value, imposing an excessive cost in terms of foregone home leisure, and the optimal response is to offset the expansion in output by reducing the domestic money supply. Conversely, if the intertemporal elasticity is less than the intratemporal elasticity, the foreign expansion reduces home output and it is optimal for the domestic central bank to respond with an expansionary policy. ${ }^{25}$ Finally, if the intertemporal and intratemporal elasticities coincide, the best response to a foreign policy shock is to "do nothing" and leave the domestic policy stance unchanged.

In this setup, the efficient level of output can be obtained only with a coordinated monetary expansion. This is for the reason discussed earlier: a country undertaking a unilateral expansion would take into account the negative terms of trade effect and hence choose a tighter policy.

Benigno (1998) develops further the strategic foundations of policy coordination in the Corsetti-Pesenti model. He considers two countries of unequal size. In light of the positive spillover in the model, noncooperation imparts a contractionary bias since each country does not internalize the gain to the other country from surprise monetary expansion. Benigno considers the sustainability of a cooperative approach to monetary policy formation, where cooperation entails a pair of monetary policies that leaves the terms of trade unchanged. Optimal cooperation leads to a joint surprise monetary expansion large enough to push both economies

\footnotetext{
${ }^{25}$ In the language of Svensson and van Wijnbergen (1989), home and foreign goods are Edgeworth-Pareto complements in the former case and Edgeworth-Pareto substitutes in the latter.
} 
to competitive output levels. Relative to the noncooperative (Nash) outcome, the terms of trade in the competitive equilibrium is lower for the larger country. Indeed, if the larger country is big enough, the negative impact on the terms of trade may be so large to leave it worse off than in the Nash equilibrium, making cooperation an unsustainable equilibrium. Benigno then considers whether partial mutual gains are feasible by delegating monetary policy to a supranational authority. Only outcomes that make both countries better off than in the Nash equilibrium are considered. In general, the smaller country is pushed to the competitive output level while the larger country retains some monopoly power (in order to preserve its terms of trade).

Tille (1998a) relaxes the Corsetti-Pesenti restriction of a unit substitution elasticity between home and foreign goods. Under the law of one price, he shows that domestic monetary expansion can be a "beggar thyself" policy if home and foreign goods are sufficiently poor substitutes, since the negative terms of trade effect dominates the expansion in domestic output. ${ }^{26}$ In contrast, if home and foreign goods are more closely substitutable, the "beggar thy neighbour" result applies.

A multi-country world raises some interesting possibilities. For instance, consider a center-periphery model where peripheral countries A and B sell similar goods to the center country $\mathrm{C}$ and country $\mathrm{C}$ in turn exports a distinct good to the periphery. In this case, a monetary expansion by country A could be "beggar thy neighbor" with respect to country

\footnotetext{
${ }^{26}$ Lombardo (1998) makes the point that the trade balance response to a positive monetary shock may be negative if home and foreign goods are sufficiently poor substitutes.
} 
$\mathrm{B}$, since devaluation switches demand in country C towards country A's goods and away from the goods of country B, but "beggar thyself"' with respect to country $\mathrm{C}$, since an increase in country's A production has a deleterious impact on its terms of trade. Corsetti et al. (1999) further consider such scenarios and rank the alternative policy responses open to country B in reaction to a monetary expansion in country A. Again, the denomination of price stickiness is crucial. If prices are set in sellers' currency, a devaluation by country A has negative expenditure-switching effects on country B. Under PTM, in which prices are set in buyers' currency, this relative price channel is switched off.

Doyle (1998) similarly examines a center-periphery model, in which central banks in the peripheral countries are of the same type but this type is not initially common knowledge. He shows how a local productivity shock may trigger a devaluation in a peripheral country, if its monetary authority places some weight on social welfare in addition to price stability. However, since all their central banks are of a common type and this action now reveals them to be not fully commited to price stability, the initial devaluation leads to speculative attacks on the other peripheral countries. In this way, "information-based" contagion can take place.

Betts and Devereux (1998) also consider international policy coordination when the law of one price fails to hold. As was noted earlier, exchange rate depreciation can actually improve a country's terms of trade under PTM, since export prices are fixed in foreign currency and exchange rate depreciation thereby raises the value of export revenues when 
converted into the domestic currency. With full PTM, monetary policy actually exerts a negative spillover effect: a domestic monetary expansion reduces foreign welfare by generating a deterioration in the foreign country's terms of trade. ${ }^{27}$

The authors analyze optimal discretionary policy in an environment in which the welfare gains from monetary expansion must be set against quadratic costs of inflation that are introduced into the model. They show that pricing to market changes the nature of international policy coordination. When the law of one price holds, policy spillovers are positive and policy coordination tends to deliver a faster rate of monetary expansion relative to the noncooperative case; with full pricing to market, policy spillovers are negative and policy coordination leads to slower rate of monetary expansion. ${ }^{28}$ In equilibrium, the inflation rate equals the rate of monetary expansion so that pricing to market restores the rationale for international policy coordination, in the sense that it leads to a costless decline in the common world inflation rate.

Finally, Devereux (1998) studies the vulnerability of a country to foreign monetary shocks under alternative exchange rate regimes. He makes the point that the merits of exchange rate flexibility as an adjustment mechanism are sharply reduced by PTM, since exchange rates do not alter relative prices and hence do not play an allocative mechanism under PTM. For this reason, a country that fixes its exchange rate does

\footnotetext{
${ }^{27}$ Tille (1998b) similarly recognizes that PTM makes "beggar thy neighbor" a more likely outcome than "beggar thyself" even with limited substitutability between home and foreign goods.

${ }^{28}$ In this way, pricing to market reverses the point made by Rogoff (1985).
} 
not necessarily suffer increased output volatility, which is a deviation from the calculus traditionally applied to the exchange rate regime decision.

\section{Section VIII: Introducing Uncertainty}

The Redux model analyzed the effects of an unanticipated monetary shock and this approach has been followed by much of the subsequent literature. A recent innovation has been to analyze sticky-price general equilibrium models in an explicitly stochastic setting.

Obstfeld and Rogoff (1998) introduce uncertainty into the CorsettiPesenti specification. As before, the assumptions of a unit elasticity of substitution between home and foreign goods and the law of one price in this model greatly simplifies the analysis since relative price movements in effect guarantee complete consumption risk-sharing, since home and foreign shares in global real income are fixed proportions. Monetary uncertainty is introduced by assuming home and foreign money stocks follow log-normal stochastic processes.

The setup permits the modelling of price setting under uncertainty. Since uncertainty affects the equilibrium prices that are chosen, it has an impact on expected consumption levels, the terms of trade and relative output levels. For instance, if the home country faces monetary uncertainty, its firms incorporate a risk premium into output prices, depressing production but improving the terms of trade. In this way, uncertainty has first-order effects on ex-ante welfare levels. A noteworthy result is that home and foreign countries have the same incentives in designing an optimal global exchange rate system, since monetary uncertainty has 
symmetric effects on ex-ante welfare in both countries, despite ex-ante differences in price setting and ex-post differences in relative output levels. Moreover, this result holds even if the home and foreign countries are different in terms of relative size, contrary to the usual presumption that small countries should care more about exchange rate stability. That said, the Obstfeld-Rogoff analysis is highly specific, in imposing the law of one price and a unit substitution elasticity between home and foreign goods.

The model also makes interesting predictions for asset pricing. For instance, the risk premium on a volatile currency may actually be negative if exchange rate movements hedge consumption volatility. This reasoning provides a novel explanation of the forward premium puzzle: a high-inflation country may also have a relatively volatile currency that hedges consumption risk, thereby simultaneously generating a positive expected depreciation rate but a negative forward premium. Moreover, it is shown that monetary uncertainty has magnified effects on the level of the exchange rate relative to the forward premium. If the forward premium is volatile, as is commonly accepted, then their analysis provides a candidate explanation for the high volatility in the actual level of the exchange rate.

Devereux and Engel (1998a) extend the uncertainty analysis of Obstfeld and Rogoff (1998) to allow for PTM. Moreover, they employ their model to make a welfare comparison between fixed and flexible exchange rate arrangements. This is interesting since the formal welfare analysis of exchange rate regimes has been confined to flexible-price envi- 
ronments until now. ${ }^{29}$ These authors show how regime evaluation crucially depends on the nature of pricing. Exchange rate systems matter not only for the variances of consumption, real balances and leisure but also for their mean values, once risk premia are incorporated into pricing decisions. Since PTM insulates consumption from exchange rate fluctuations, floating exchange rates are less costly under PTM than under producer currency pricing and a flexible regime will dominate pegging whenever agents are at least as risk averse as logarithmic consumers (which is the empirically relevant range). Under producer currency pricing, in contrast, fixed exchange rates will be preferred if risk aversion is sufficiently high. ${ }^{30}$

Bacchetta and van Wincoop (1998) also analyze monetary uncertainty under PTM but in a simpler two-period dynamic framework that allows them to analyze the impact of nonseparabilities between consumption and leisure in preferences. A key result is that monetary uncertainty makes it optimal to charge different prices in home and foreign markets: if consumption and leisure are substitutes, a higher price is charged to foreign relative to domestic customers, thereby reducing the volume of international trade. In this way, the old fear that exchange rate uncertainty reduces trade is formalized in a general equilibrium setting in which ex-

\footnotetext{
${ }^{29}$ See, amongst others, Helpman (1981). There is a long tradition of comparing exchange rate regimes under nominal rigidities but this literature has employed ad hoc loss functions: see Genberg (1989) for a survey.

${ }^{30}$ Devereux and Engel (1998b) allow for internationalized production, by which home firms use foreign labour to produce for the foreign market and, conversely, foreign firms employ home workers to produce for the home market. Under full risk-sharing, home and foreign real wages are equalized so the internationalization of production does not alter the prices charged by firms. Under PTM, internationalized production insulates domestic employment from foreign monetary shocks since changes in foreign demand for home goods are met by an increase in foreign production by domestic firms using foreign labor.
} 
change rate volatility and trade volumes are jointly determined from the stochastic properties of the underlying fundamentals.

The intuition for the result is that the correlations between domestic labor costs and home and foreign levels of demand are central in determining home and foreign output prices. Under separable preferences, wages are more positively correlated with domestic demand than foreign demand. On the one side, this should raise the home price relative to the foreign price. However, the positive correlation means that wages are high precisely when demand is high and firms are able to absorb an increase in costs. With separable preferences, these effects cancel out and the same price is charged in both markets. When consumption and leisure are complements, the correlation between wages and domestic demand increases yet further and the former effect dominates, leading to a relatively higher domestic price. In contrast, the correlation between wages and domestic demand falls when consumption and leisure are substitutes, such that the latter effect is more important and the home price falls below the foreign price. In this case, production is orientated to the home market and the volume of international trade declines.

Moreover, uncertainty affects trade volumes even with complete international financial markets. As also noted by Devereux and Engel (1998), PTM means that home and foreign consumers face different relative prices and so risk-sharing does not imply equalization of home and foreign consumption. To illustrate this point, Bacchetta and van Wincoop (1998) show that the existence of a forward currency market cannot eliminate the real effects from uncertainty. Although forward hedging 
guarantees the domestic currency value of a given amount of foreign currency revenues, it cannot undo the impact of uncertainty about the level of any such foreign currency revenues.

Finally, Bacchetta and van Wincoop (1998) also analyze the impact of monetary uncertainty on net capital flows. The source of net capital flows is a shock to the domestic discount rate. ${ }^{31}$ Uncertainty and PTM means that foreign bonds are riskier than domestic bonds (again assuming the rate of relative risk aversion is greater than one), leading to a currency risk premium, a preference for domestic assets and a decline in net capital flows.

\section{Section IX: Market Structure}

Most of the literature analyzes a monopolistic competition structure in which firms face a constant elasticity of demand and accordingly set prices as a fixed markup over marginal cost. ${ }^{32}$ This certainly simplifies the analysis by ruling out strategic interdependence among firms. However, by the same token, the lack of strategic interdependence makes it impossible to address potentially important transmission mechanisms, such as the impact of real exchange rate movements on relative market shares in particular industries.

As was discussed earlier, Bergin and Feenstra (1998a, 1998b) move away from monopolistic competition by introducing translog con-

\footnotetext{
${ }^{31}$ As the authors point, this shock must be imperfectly verifiable - otherwise it could be simply accomodated via an appropriate international transfer under perfect risksharing.

${ }^{32}$ Alternatively, as in Corsetti and Pesenti (1998), the goods market can be modelled as competitive but with a monopolistic labor market.
} 
sumer preferences. With this utility specification, strategic considerations are introduced into price setting since a firm must take into account the pricing decisions of other firms in determining its optimal markup. In this way, the markup partially absorbs the impact of shocks and exchange rate pass-through is less than complete.

Chang and Devereux (1998) extend the Rotemberg-Woodford oligopolistic model to an open economy setting. In this framework, CES preferences are retained for different categories of goods ("industries") but an oligopoly of firms operates within each industry. An equilibrium is studied in which firms within each industry collude and the markup that sustains collusion moves countercyclically (demand is more elastic at higher output levels). The authors examine dynamic properties of real exchange rate behavior in the model. However, since this is a flexible-price model, the impact of monetary shocks under nominal rigidities cannot be studied.

Some other interesting market structures that highlight strategic interaction have yet to be properly studied in dynamic general equilibrium settings. Fitoussi and Phelps (1988) and Phelps (1994) constructed reduced-form models in which a firm can win a persistent increase in its market share by temporarily reducing its relative price. This alters the international transmission mechanism: real depreciation allows domestic firms to raise their overall market share. Dixon (1994) also considers a framework in which home and foreign firms directly interact. He specifies a static model in which there are industries that sell exclusively to the domestic market. There is a duopoly in each industry, with home and for- 
eign firms engaged in Cournot competition. Home and foreign wages are sticky in their respective currencies. In this setup, a domestic devaluation reduces the costs of domestic firms relative to foreign rivals, improving their competitiveness and leading to a gain in their market share. This battle for market share provides an additional adjustment margin that is absent in the monopolistic competition framework. It would be interesting to incorporate such strategic interaction between home and foreign firms in the dynamic models emphasized in this survey.

\section{Section X: The Small Open Economy Model}

The literature has largely emphasized two-country global economy models. An advantage of this approach is that it highlights international transmission channels and allows interest rates and asset prices to be endogenously determined in international capital markets. Moreover, as is discussed in section 7, a global approach permits the analysis of international policy interdependence. However, these benefits come at the price of considerable model complexity and may not be of compelling importance for the analysis of small open economies.

Indeed, in the appendix to the Redux paper, Obstfeld and Rogoff sketch a small open economy version of their model. Monopolistic competition and price stickiness exist in the nontraded sector but traded output is modelled as an endowment with the domestic currency price equal to the exogenous world price times the exchange rate. The subutility function for consumption specifies that preferences for traded and 
nontraded good are log separable

$$
U\left(C_{T}, C_{N}\right)=\alpha \log \left(C_{T}\right)+(1-\alpha) \log \left(C_{N}\right)
$$

where $\alpha$ is the fixed share of tradables in total consumption, $C_{T}$ is consumption of the single tradable good and $C_{N}$ is a composite of the differentiated varieties of the nontraded good. The economy has access to the international capital market, which a offers riskless real bond denominated in units of the tradable good. The discount rate is assumed to be equal to the world interest rate.

Unlike the Redux model, a permanent monetary shock does not generate a current account imbalance in this setup. Since traded output is taken to be fixed, current account behavior is determined by the time path for tradables consumption. Log-separable preferences and a discount rate equal to the world interest rate implies that the optimal path for tradables consumption is perfectly flat, so that the current account always remains in balance.

However, exchange rate overshooting is possible in this environment. Since a monetary shock does not generate any current account imbalance, money is neutral in the long-run and the nominal exchange rises in proportion to the money shock in the new steady-state. If the nominal exchange rate were to rise in proportion to the money shock in the short-run, the supply of real balances would increase by only $1-\alpha$ that amount since the price of tradables (the exchange rate) has only the weight $\alpha$ in the overall price level and the price of nontradables is fixed. In that case, the demand for real balances would rise by the increase in ag- 
gregate consumption times the consumption elasticity of money demand. Aggregate consumption rises by $1-\alpha$ times the increase in nontradables consumption (tradables consumption is fixed). So the rise in the demand for real balances only matches the increase in supply if the consumption elasticity of money demand is unity. If the consumption elasticity of money demand is less than one, then monetary equilibrium requires a decline in the short-run nominal interest rate and hence overshooting of the nominal exchange rate. In fact, this is precisely the same overshooting condition as in the original Dornbusch (1976) model, since the elasticity of (nontraded) output with respect to the real exchange rate is set equal to unity in this setup.

Lane (1997) applies this model to analyze discretionary monetary policy and the impact of openness on the equilibrium inflation rate. A more open economy is one with a smaller nontraded sector (a larger $\alpha$ in equation [12]) and thereby gains less from surprise inflation since the output gain, which is exclusively obtained in the nontraded sector, from a monetary expansion is diminished. Following Barro and Gordon (1983), the equilibrium inflaiton rate under discretionary monetary policy is an increasing function of the gains to unexpected inflation: as such, the prediction is that more open economies have lower equilibrium inflation rates. This inverse relationship between openness and inflation holds even for small economies that face exogenous world prices for tradables and so is independent of the terms of trade mechanism emphasized by Rogoff (1985) and Romer (1993).

Lane (1998) considers an alternative specification in which the 
consumption subutility function is of the CRRA form

$$
U(C)=\frac{\sigma}{\sigma-1} C^{\frac{\sigma-1}{\sigma}} \quad \sigma>0
$$

where the consumption index $C$ is a CES aggregate of traded and nontraded goods

$$
C=\left[\gamma^{\frac{1}{\theta}} C_{T}^{\frac{\theta-1}{\theta}}+(1-\gamma)^{\frac{1}{\theta}} C_{N}^{\frac{\theta-1}{\theta}}\right]^{\frac{\theta}{\theta-1}} \quad \theta>0
$$

Under this specification, a monetary shock may generate a current account imbalance. The nonseparability between tradable and nontradable consumption means that shocks to the nontraded sector have spillover effects on the level of tradables consumption and hence on the current account. ${ }^{33}$ The sign of the current account response depends on the interplay between the intertemporal elasticity of substitution $\sigma$ and the intratemporal elasticity of substitution $\theta$. The former guides the willingness to substitute consumption across periods and the latter the degree of substitutability between traded and nontraded consumption. If $\sigma<\theta$, the latter effect dominates: the rise in nontraded output and consumption leads to a decline in traded consumption and a positive monetary shock thereby generates a current account surplus. In contrast, a current account deficit occurs if $\sigma>\theta$. Finally, the current account remains in balance only if $\sigma=\theta .^{34}$ In this way, the model illustrates that traditional Mundell-Fleming results are sensitive to the precise specification of a model's microfoundations. In this particular case, preferences must

\footnotetext{
${ }^{33}$ See also Obstfeld and Rogoff (1996, Chapter 4).

${ }^{34}$ The log-separable preferences analyzed above are an example in which $\sigma=\theta=1$.
} 
be such that the intertemporal elasticity of substitution exceeds the intratemporal elasticity of substitution if a positive monetary shock is to generate a current account surplus. ${ }^{35}$

An alternative modelling approach is provided by Kollmann (1997). He considers a semi-small open economy which produces and consumes only tradable goods. It faces a downward-sloping aggregate export demand function but import prices, the level of global aggregate demand and the international interest rate are all exogenous to domestic conditions. There are Cobb-Douglas preferences between home and foreign goods. As in the PTM models reviewed above, export prices are assumed to be sticky in foreign currency.

\section{Section XI: Empirics}

Thus far, the literature has been primarily theoretical in focus. That said, some authors have attempted to gain a sense of the quantitative importance of some of the mechanisms emphasized in the theoretical models, either via calibration exercises or econometric investigation.

\footnotetext{
${ }^{35}$ Velasco (1997) considers a non-monetary flexible-price version of a small open economy model. He allows for the entry of firms into the nontraded sector upon the payment of a fixed cost. New firms produce extra varieties of the nontraded good. Entry means that the output of any individual firm in the nontraded sector is fixed: any variation in total nontraded output must come from variation in the number of firms. Preferences are nonseparable in consumption and leisure such that the marginal utility of consumption is increasing in work effort. Velasco shows that this setup can generate multiple equilibria. With the discount rate equal to the interest rate and a constant endowment of the traded good, one equilibrium involves constant values for all variables. Under some parameter restrictions, an alternative equilibrium exists in which consumption and output of nontraded goods, and consumption of traded goods, oscillate between high and low levels; the real wage and real exchange rate are procyclical and the current account countercyclical.
} 


\section{A : Matching Unconditional Moments}

One calibration method is to match the unconditional moments generated by the model to the unconditional moments observed in the data. In this approach, the goal is to establish what proportion of aggregate fluctuations can be explained by a single source of shocks. Chari et al. (1998) and Kollmann $(1997,1998)$ have followed this approach. Much can be learned from these exercises in terms of the quantitative properties of sticky-price dynamic general equilibrium models. However, even if monetary shocks only account for a fraction of the aggregate economic fluctuations over a given time interval, this is not inconsistent with the existence of nominal rigidities or an important role for monetary policy in responding to other disturbances. Moreover, it is widely accepted that the unconditional variances of nominal and real exchange rates are infected by considerable market noise that is unrelated to macroeconomic fundamentals. ${ }^{36}$ For these reasons, this calibration method is not sufficient in obtaining an overall empirical evaluation of this class of models.

\section{B : VAR Evidence}

An alternative is to evaluate models on their performance in describing how the economy responds to a macroeconomic shock. For this purpose, useful empirical evidence is provided by the the impulseresponse functions generated by VAR econometric models. In influential contributions, Clarida and Gali (1994) and Eichenbaum and Evans (1995)

\footnotetext{
${ }^{36}$ See Flood and Rose (1995, 1998).
} 
employed VARs to show that monetary shocks do move the real exchange rate in a manner that is qualitatively consistent with the predictions of sticky-price models. Betts and Devereux (1997) update the EichenbaumEvans VAR model and extend it to include the trade balance in the system. They show that a calibrated PTM model does well in matching the conditional moments in the data and clearly outperforms the PPP-based Redux model which cannot generate real exchange rate movements or high international output correlations relative to consumption correlations. ${ }^{37}$

A number of recent papers have attempted to establish whether monetary disturbances indeed affect the current account, in line with the qualitative predictions of some of the sticky-price intertemporal models. Lane (1998) estimates a VAR model using the identification assumption is that monetary shocks have no long-run effect on the current account, consistent with the theoretical models described in earlier sections. Kumar and Prasad (1997) and Lee and Chinn (1998) rather adopt the identification restriction that monetary shocks have no long-run impact on the real exchange rate, a condition that holds only in a subset of the models reviewed above. Lane (1998) and Betts and Devereux (1998) also consider a short-run recursive identification scheme, extending the system of Eichenbaum and Evans (1995) to include a trade balance measure. In broad terms, each of these papers find that positive nominal shocks tend to improve the current account position. ${ }^{38}$

\footnotetext{
${ }^{37}$ Betts and Devereux (1998) provide additional VAR evidence.

${ }^{38}$ Lane (1998) and Betts and Devereux (1998) find a J-curve response of the trade balance to monetary shocks, such the impact effect is negative, with the improvement only occurring with a lag. Betts and Devereux provide a non-traditional explanation for the J-curve. The PTM assumption means that home and foreign consumption are
} 
So far, the emphasis has been placed on capturing in the data the real effects of monetary shocks. However, as emphasized by Gali (1998) and Basu et al (1998), nominal rigidities also influence the transmission of real shocks, such as fiscal or technology disturbances. For instance, in a closed-economy setting, Basu et al (1998) show how positive technology shocks can have a negative impact effect on the level of output in the presence of nominal rigidities and that such a model fits the data better than flexible-price alternatives. It would be interesting to extend this work to the open economy and investigate, in sticky-price settings, the impact of non-monetary shocks on the real exchange rate, the current account and the international transmission of these disturbances.

\section{$C$ : Other Evidence}

More indirect predictions of the theoretical literature have also been empirically investigated. In a static monopolistic competition model, Romer (1993) showed that a more open country gains less from outputenhancing surprise inflation, since it is hurt more by the negative terms of trade effect of a rise in output. Empirically, in a large cross-section of countries, Romer found that more open economies indeed had lower average inflation rates over 1973-88. However this explanation relies on an endogenous terms of trade mechanism which is arguably unimportant for small countries. As was discussed in Section 10 above, the theoreti-

delinked in the short-run. The monetary expansion stimulates domestic output but domestic consumption rises even more quickly, generating a trade deficit. An investment boom also occurs which raises the medium-run level of output. However, PPP is restored in the medium-run so that the domestic output increase is shared by home and foreign consumers, requiring a trade balance surplus. 
cal model of Lane (1997) shows that inflation and openness are inversely related even for countries that face exogenous terms of trade. In his empirical work, Lane revisits the Romer specification and shows that controlling for country size magnifies the negative relationship between openness and inflation. Moreover, holding fixed openness, larger countries have lower inflation rates which is consistent with the operation of the terms of trade channel. ${ }^{39}$

Hau (1998b) implements an empirical test of the prediction in Hau (1998a) that a monetary shock has a bigger impact on the real exchange rate, the larger is the relative size of the nontraded sector. Hau finds that real exchange rate volatility and openness are indeed inversely correlated in a large cross-section of countries, even when openness is treated as endogenous and there are controls for central bank independence and the type of exchange rate regime.

Obstfeld and Rogoff (1995b, 1996) and Gagnon (1996) present evidence of a significant relationship between net foreign assets and the real exchange rate among OECD economies. This empirical finding provides indirect support for the notion that even temporary disturbances can have persistent effects, since current account imbalances alter net foreign assets and hence can have long-lasting real effects. Finally, using European Union data, Caselli (1998) shows that the differential in private consumption growth rates across countries is inversely related to the dif-

\footnotetext{
${ }^{39}$ Campillo and Miron (1997) show that the openness-inflation relationship is robust to an extension of the data set and the inclusion of a host of extra control variables. Lane (1999, forthcoming) extends the empirical analysis to show that, consistent with the theory, more open economies have slower average rates of nominal exchange rate depreciation.
} 
ferential in public (government) consumption growth rates, in line with the fiscal predictions of microfounded Redux-style models.

\section{D : Parameter Estimation}

Finally, as the discussion in earlier sections has made clear, many predictions of the theoretical models are highly sensitive to the choice of parameter values. For this reason, it is highly desirable to obtain more empirical evidence on which values are plausible for such key parameters as the intertemporal elasticity of substitution, the elasticities of substitution between home and foreign goods and between tradables and nontradables, to name just a few. Summers (1991) is sceptical that such parameters can be estimated with any precision.

\section{Section XII: Conclusions}

This paper has reported on a new literature that is attempting to reshape how international macroconomics is done. Although the impact effects of shocks on real variables in many cases are largely similar to those predicted by traditional reduced-from models, the intertemporal nature of the recent models also allow the tracking of dynamic effects. More importantly, the solid microfoundations embedded in these models permits welfare analysis, which can generate some surprising results. In turn, welfare analysis opens the door to rigorous policy evaluation, providing new foundations for the analysis of international policy interdepen-

dence. In related fashion, the stochastic versions of these new models are well-designed for making meaningful comparisons across different policy 
regimes.

As is readily apparent from this survey, many welfare results are highly sensitive to the precise denomination of price stickiness, the specification of preferences and financial structure. For this reason, any policy recommendations emanating from this literature must be highly qualified. This is an issue of some concern, since the new open economy macroeconomics will be of only limited interest in policy circles unless researchers converge on a "preferred" specification that is buttressed by extensive supporting empirical evidence. For all that, the many unanswered questions that remain should ensure that this burgeoning field is likely to grow yet further in the coming years.

\section{References}

[1] Andersen, Torben M. (1998), "Persistency in Sticky Price Models," European Economic Review, 42, 593-603.

[2] Bacchetta, Philippe and van Wincoop, Eric (1998), "Does Exchange Rate Stability Increase Trade and Capital Flows?", Federal Reserve Bank of New York Research Paper \#9818.

[3] Beaudry, Paul and Michael Devereux (1995), "Money and the Real Exchange Rate with Sticky Prices and Increasing Returns," CarnegieRochester Conference Series on Public Policy, 43, 55-101.

[4] Benigno, Pierpaolo (1998), "A Simple Approach to International Monetary Policy Coordination," work in progress, Princeton University. 
[5] Bergin, Paul (1995), "Mundell-Fleming Revisited: Monetary and Fiscal Policies in a Two-Country Dynamic Equilibrium Model with Wage Contracts," mimeo, University of California at Davis.

[6] Bergin, Paul (1998) "Devaluations, Consumption Smoothing and the Current Account," mimeo, University of California at Davis.

[7] Bergin, Paul and Robert Feenstra (1998a), "Pricing to Market, Staggered Contracts and Real Exchange Rate Persistence," mimeo, University of California at Davis.

[8] Bergin, Paul and Robert Feenstra (1998a), "Staggered Pricing and Endogenous Persistence," mimeo, University of California at Davis.

[9] Blanchard, Olivier and Nobuhiro Kiyotaki (1987), "Monopolistic Competition and the Effects of Aggregate Demand," American Economic Review, 77, 647-666.

[10] Betts, Caroline and Michael Devereux (1996), "The Exchange Rate in a Model of Pricing to Market," European Economic Review, 40, $1007-1021$.

[11] Betts, Caroline and Michael Devereux (1997), "The International Monetary Transmission Mechanism: A Model of Real Exchange Rate Adjustment under Pricing-to-Market," mimeo, University of British Columbia/Hong Kong University of Science and University of Southern California.

[12] Betts, Caroline and Michael Devereux (1998a), "Exchange Rate Dynamics in a Model of Pricing to Market," Journal of International Economics, forthcoming. 
[13] Betts, Caroline and Michael Devereux (1998b), "The International Effects of Monetary and Fiscal Policy in a Two-Country Model," mimeo, University of Southern California and University of British Columbia/Chinese University of Hong Kong.

[14] Blanchard, Olivier (1983), "Price Asynchronization and Price Level Inertia," in (Ruidger Dornbusch, Miguel Simonsen, eds.) Inflation, Debt and Stabilization, Cambridge, MA: MIT Press.

[15] Calvo, Guillermo (1983), "Staggered Prices in a Utility Maximizing Framework," Journal of Monetary Economics, 12, 983-998.

[16] Campillo, Marta and Jeffrey Miron (1997), "Why Does Inflation Differ Across Countries?," in (Christina D. Romer and David Romer, eds.) Reducing Inflation: Motivation and Strategy, Chicago, IL: University of Chicago Press.

[17] Caselli, Paola (1998), "Fiscal Consolidations under Fixed Exchange Rates," Temi di discussione del Servisio Studi No. 336, Banca d'Italia.

[18] Chang, Roberto and Michael Devereux (1998), "Dynamic Collusion and the Real Exchange Rate," work in progress, University of British Columbia/Hong Kong University of Science and Technology and Federal Reserve Bank of Atlanta.

[19] Chari, V.V., Pat Kehoe and Ellen McGrattan (1998a), "Monetary Shocks and Real Exchange Rates in Sticky Price Models of International Business Cycles," Federal Reserve Bank of Minneapolis Research Department Staff Report \#223, (initial version February 1996, revised February 1998). 
[20] Chari, V.V., Pat Kehoe and Ellen McGrattan (1998b), "Sticky Price Models of the Business Cycle: Can the Contract Multiplier Solve the Persistence Problem?," Federal Reserve Bank of Minneapolis Research Department Staff Report \#217, (initial version September 1996, revised May 1998).

[21] Clarida, Richard and Jordi Gali, "Sources of Real Exchange Rate Fluctuations: How Important Are Nominal Shocks?," CarnegieRochester Conference Series on Public Policy, 41, 1-56.

[22] Cooper, Russ and Andrew John, "Coordinating Coordination Failures in a Keynesian Economy," Quarterly Journal of Economics, 103, 441463.

[23] Corsetti, Giancarlo and Paolo Pesenti (1998), "Welfare and Macroeconomic Interdependence," mimeo, Yale University and Princeton University.

[24] Corsetti, Giancarlo, Paolo Pesenti, Nouriel Roubini and Cedric Tille (1999), "Trade and Contagious Devaluations: A Welfare-Based Approach," NBER Working Paper \#6889.

[25] Devereux, Michael (1997), "Real Exchange Rates and Macroeconomics: Evidence and Theory," Canadian Journal of Economics, 30, 773-808.

[26] Devereux, Michael (1998), "Do Fixed Exchange Rates Inhibit Macroeconomic Adjustment?," mimeo, University of British Columbia/Hong Kong University of Science and Technology. 
[27] Devereux, Michael and Charles Engel (1998a), "Fixed versus Floating Exchange Rates: How Price Setting Affects the Optimal Choice of Exchange-Rate Regime," mimeo, University of British Columbia/Hong Kong University of Science and Technology and University of Washington.

[28] Devereux, Michael and Charles Engel (1998b), "The Choice of Exchange-Rate Regime: Price-Setting Rules and Internationalized Production," mimeo, University of British Columbia/Hong Kong University of Science and Technology and University of Washington.

[29] Dixon, Huw (1994), "Imperfect Competition and Open Economy Macroeconomics," in (Frederick van der Ploeg, ed.) The Handbook of International Macroeconomics, Oxford: Basil Blackwell.

[30] Dornbusch, Rudiger (1976), "Expectations and Exchange Rate Dynamics," Journal of Political Economy, 84, 1161-1177.

[31] Doyle, Brian M. (1998), "Reputation and Currency Crises (or 'Countries of a Feather Devalue Together')," mimeo, Princeton University.

[32] Eichenbaum, Martin and Charles Evans (1995), "Some Empirical Evidence on the Effects of Monetary Policy Shocks on Real Exchange Rates," Quarterly Journal of Economics, 110, 975-1009.

[33] Engel, Charles (1998), "Accounting for Real Exchange Rate Changes," Journal of Political Economy, forthcoming.

[34] Fitoussi, Jean-Paul and Edmund Phelps (1988), The Slump in Europe, Oxford: Basil Blackwell. 
[35] Flood, Robert and Andrew Rose (1995), "Fixing Exchanges Rates: A Virtual Quest for Fundamentals," Journal of Monetary Economics, $36,3-37$.

[36] Flood, Robert and Andrew Rose (1998), "Understanding Exchange Rate Volatility Without the Contrivance of Macroeconomics," CEPR Discussion Paper No. 1944.

[37] Friberg, Richard (1998), "In Which Currency Should Exporters Set Their Prices?," Journal of International Economics, 45, 59-76.

[38] Gagnon, Joseph (1996), "Net Foreign Assets and Equilibrium Exchange Rates: Panel Evidence," mimeo, International Finance Division, Board of Governors of the Federal Reserve System.

[39] Gali, Jordi, "Technology, Employment and the Business Cycle: Do Technology Shocks Explain Aggregate Fluctuations?," American Economic Review, forthcoming.

[40] Genberg, Hans (1989), "Exchange Rate Management and Macroeconomic Policy: A National Perspective," Scandinavian Journal of Economics, 91, 439-469.

[41] Goldberg and Knetter (1996), "Goods Prices and Exchange Rates: What Have We Learned?," Journal of Economic Literature, ... .

[42] Goodfriend, Marvin and Robert King (1997), "The New Neoclassical Synthesis and the Role of Monetary Policy," in (Ben Bernanke and Julio Rotemberg, eds.) NBER Macroeconomics Annual 1997, Cambridge, MA: MIT Press. 
[43] Hau, Harald (1998a), "Exchange Rate Determination: The Role of Factor Price Rigidities and Nontradables," Journal of International Economics, forthcoming.

[44] Hau, Harald (1998b), "Real Exchange Volatility and Economic Openness: Theory and Evidence," mimeo, ESSEC.

[45] Helpman, Elhanan (1981), "An Exploration in the Theory of Exchange-Rate Regimes," Journal of Political Economy, 10, 263-283.

[46] Kimball, Miles (1995), "The Dynamic Implications of the Quantitative NeoMonetarist Model," Journal of Money, Credit and Banking, $27,1241-1277$.

[47] Kollman, Robert (1997), "The Exchange Rate in a DynamicOptimizing Current Account Model with Nominal Rigidities: A Quantitative Investigation," International Monetary Fund Working Paper 97/7.

[48] Kollman, Robert (1998), "International Financial Markets and Business Cycles: A General Equilibrium Approach with Money and Nominal Rigidities," mimeo, University of Paris XII.

[49] Krugman, Paul (1995), "What Do We Need to Know About the International Monetary System?," in (Peter Kenen, ed.) Understanding Interdependence: The Macroeconomics of the Open Economy, Princeton, NJ: Princeton University Press.

[50] Lane, Philip R. (1997), "Inflation in Open Economies," Journal of International Economics, 42, 327-347. 
[51] Lane, Philip R. (1998), "Money Shocks and the Current Account," mimeo, Trinity College Dublin.

[52] Lane, Philip R. (1999), "What Determines the Nominal Exchange Rate? Some Cross-Sectional Evidence," Canadian Journal of Economics, February 1999, forthcoming.

[53] Lee, Jaewoo and Menzie Chinn (1998), "The Current Account and the Real Exchange Rate: A Structural VAR Analysis of Major Currencies," NBER Working Paper \#6495.

[54] Lombardo, Giovanni (1998), "On the Trade Balance Response to Monetary Shocks: The Marshall-Lerner Conditions Reconsidered," mimeo, University of York.

[55] Obstfeld, Maurice and Kenneth Rogoff (1995a), "Exchange Rate Dynamics Redux," Journal of Political Economy, 103, 624-660.

[56] Obstfeld, Maurice and Kenneth Rogoff (1995b), "The Intertemporal Approach to the Current Account," in (Gene Grossman and Kenneth Rogoff, eds.) Handbook of International Economics, Volume 3, Amsterdam: North-Holland.

[57] Obstfeld, Maurice and Kenneth Rogoff (1996), Foundations of International Macroeconomics, MIT Press, Cambridge, MA.

[58] Obstfeld, Maurice and Kenneth Rogoff (1998), "Risk and Exchange Rates," mimeo, University of California at Berkeley and Princeton University. 
[59] Phelps, Edmund (1994), Structural Slumps, Cambridge, MA: Harvard University Press.

[60] Prasad, Eswar and Manmohan Kumar (1997), "International Trade and the Business Cycle," mimeo, International Monetary Fund.

[61] Rogoff, Kenneth (1985), "Can International Monetary Policy Coordination be Counterproductive?," Journal of International Economics, $18,199-217$.

[62] Rogoff, Kenneth (1996), "The Purchasing Power Parity Puzzle," Journal of Economic Literature, 34, 647-688.

[63] Romer, David (1993), "Openness and Inflation: Theory and Evidence," Quarterly Journal of Economics, 108, 870-903.

[64] Rotemberg, Julio and Michael Woodford (1992), "Oligopolistic Pricing and the Effects of Aggregate Demand on Economic Activity," Journal of Political Economy, 100, 1153-1207.

[65] Senay, Ozge (1998), "The Effects of Goods and Financial Market Integration on Macroeconomic Volatility," The Manchester School Supplement, 66, 39-61.

[66] Summers, Lawrence (1991), "The Scientific Illusion in Empirical Macroeconomics," Scandinavian Journal of Economics, 93, 129-148.

[67] Sutherland, Alan (1996), "Financial Market Integration and Macroeconomic Volatility," Scandinavian Journal of Economics, 98, 521-539. 
[68] Svensson, Lars and Sweder van Wijnbergen (1989), "Excess Capacity, Monopolistic Competition and International Transmission of Monetary Disturbances," Economic Journal, 99, 785-805.

[69] Taylor, John (1980), "Aggregate Dynamics and Staggered Contracts," Journal of Political Economy, 88, 1-23.

[70] Tille, Cedric (1997), "The International Welfare Effect of Monetary Policy under Pricing to Market," mimeo, Princeton University.

[71] Tille, Cedric (1998a), "Substitutability and Welfare," mimeo, Federal Reserve Bank of New York.

[72] Tille, Cedric (1998b), "The Welfare Effects of Monetary Shocks under Pricing to Market: A General Framework," mimeo, Federal Reserve Bank of New York.

[73] Velasco, Andres (1997), "Multiplicity and Cycles in a Real Model of the Open Economy," mimeo, New York University.

[74] Warnock, Francis E. (1998), "Idiosyncratic Tastes in a Two-Country Optimizing Model: Implications of a Standard Presumption," International Finance Discussion Paper No. 631, Board of Governors of the Federal Reserve System,. 